\title{
Usaha Mengatasi Ancaman Disintegrasi Bangsa dalam Rangka Memupuk Persatuan dan Kesatuan Bangsa Pasca Kemerdekaan
}

\author{
Yuvensius e.s.mandonsa
}

Institut IImu Kesehatan Strada Indonesia

Yuvensius13@gmail.com

\begin{abstract}
ABSTRAK
Pemilihan topik kegiatan ini didasarkan pada perhatian penulis terhadap perkembangan generasi muda pada era sekarang ini yang sangat memprihatinkan. Pengetahuan terhadap suatu nilai kesejarahan sudah mulai menurun drastis. Mereka sebagian besar hanya membicarakan masalah kekinian saja serta mengesampingkan masa lalu.

Sejarah mereka anggap hanya sebagai barang antik yang harus dimuseumkan. Kalangan generasi muda sekarang banyak yang mengidap penyakit amnesia sejarah. Padahal apabila kita amati secara cermat banyak sekali persoalan sekarang ini yang bisa diselesaikan dengan sejarah.
\end{abstract}

Kembali pada tujuan awal bahwa belajar sejarah itu bukan hanya saja untuk mengetahui masa lampau, tetapi lebih dari itu, yaitu untuk melatih manusia lebih bersikap bijaksana dalam menyelesaikan persoalan. Persoalan bangsa selama ini menjadi suatu penghambat dalam majunya suatu negara.

Lalu dengan kompleksnya persoalan negara itu, selanjutnya mau dibawa ke arah mana negara ini di masa depan.

Semua itu tentunya tugas generasi muda sebagai generasi penerus bangsa. Metode penelitian yang digunakan dalam penyusunan karya ilmiah ini adalah metode penelitian sejarah, dengan cara merekonstruksi masa lampau melalui proses pengujian dan analisis secara kritis terhadap rekaman dan peninggalan masa lampau.

Secara garis besar penelitian sejarah terbagi menjadi empat tahapan yaitu, heuristik, kritik, interpretasi dan historiografi.

Kata kunci: Disintegrasi, Bangsa, Pasca Kemerdekaan.

\section{KATA PENGANTAR}

Potensi disintegrasi bangsa di Indonesia dewasa ini mengalami ancaman serta permasalahan yang kompleks dan harus segera dicarikan solusi ataupun jalan keluar serta pemecahan yang tepat.

Apabila hal ini tidak segera dicarikan solusinya, maka akan berdampak pada meningkatnya eskalasi konflik yang berorientasi pada pemisahan diri dari NKRI.

Kondisi semacam ini juga dipengaruhi dengan surutnya rasa nasionalisme yang ada di dalam masyarakat serta dapat berkembang menjadi fenomena atau konflik yang terus berkepanjangan dan 
akhirnya mengarah pada disintegrasi bangsa.

Hal itu terjadi karena kompleksnya pengertian bangsa sendiri bangsa adalah suatu wilayah komunitas dari tanah kelahiran, seorang dilahirkan ke dalam suatu bangsa yang bercirikan pada fakta biologis ke dalam sejarah, struktural, teritorial dari komunitas kebudayaan (Grosby, 2011, p. 9).

Untuk menanggulangi permasalahan tersebut memang sangat diperlukan landasan pemikiran yang pada dasarnya semua itu sudah ditetapkan oleh pemerintah sendiri, landasan pemikiran yang dimaksud adalah Pancasila sebagai landasaan idiil, UUD 1945 sebagai landasan konstitusional, Wawasan Nusantara sebagai landasan visional, serta ketetapan MPR Nomor V/MPR/200 tentang Pemantapan Persatuan dan Kesatuan Nasional.

Dalam rangka merumuskan kebijakan tersebut, tentunya harus ada upaya dan strategi yang harus dibangun dalam rangka menanggulangi serta mencegah ancaman disintegrasi bangsa dan sangat penting untuk mengetahui karakteristik apa penyebab terjadinya ancaman disintegrasi bangsa yang telah melanda saat ini. Dengan demikian maka sangatlah perlu untuk dapatnya dianalisa melalui beberapa faktor yang penting yang di antaranya adalah sebagai berikut:

1) Pembangunan moral generasi bangsa melalui penanaman rasa nasionalisme yang tinggi;

2) Harus mampu mengelola keanekaragaman masyarakat Indonesia;

3) Mencegah timbulnya segala macam konflik;
4) Stabilitas keamanan yang mantab dan dinamis;

5) Penegakkan hukum yang berlaku;

6) Analisis pengaruh otonomi daerah;

\section{HASIL DAN PEMBAHASAN}

Pentingnya Pembangunan Moral Melalui Penanaman Nasionalisme di Lingkungan Sekolah.

Nasionalisme merupakan manifestasi kesadaran bernegara akan tumbuh dan berkembang di negara merdeka serta mampu berkembang lebih leluasa yang hal ini didasarkan pada kemampuan dan kemauan para warga negara itu sendiri tanpa mengalami tekana dari pihak lain.

Sebagai warga negara yang baik hendaknya harus mampu menerapkan cara berpikir nasional yang hal itu merupakan cara berpikir seseorang terhadap kesadaran bernegara dan mempunyai ciri-ciri khusus yang diantaranya berupa norma obyektif artinya selalu mengutamakan kepentingan kehidupan nasional (Muljana, 2008, pp. 67).

Apabila diibaratkan nyawa bagi manusia, nasionalisme itu sendiri merupakan jantung kehidupan suatu negara yang berperan sebagai tiang utama tegaknya negara.

Pada masa-masa seperti ini sebenarnya lembaga-lembaga pendidikan lebih tepat sebagai fasilitator dalam menumbuh kembangkan rasa nasionalisme terhadap generasi muda.

Sekolah merupakan lembaga pendidikan yang pada hakikatnya tidak akan lepas dari tudingan masyarakat apabila disinyalir terdapat kenakalan remaja atau bahkan 
tawuran antar pelajar. Kenakalan serta merosotnya moral siswa dewasa ini seakan-akan merupakan sebuah cerminan bahwa sekolah sebagai lembaga pendidikan mengalami kegagalan dalam membentuk karakter serta peradaban bangsa Indonesia yang mempunyai martabat yang tinggi. Beban moral yang berat hal ini memang tertujukan kepada guru agama serta guru PPKn yang memang menjadi sasaran untuk mendapatkan tudingan serta dituduh gagal dalam membentuk moral serta kepribadian siswa.

Pada dasarnya apabila dikaji secara detail ternyata penyebab kemerosotan moral pada diri anak bukan hanya karena adanya penurunan akhlak, serta kurangnya pemahaman terhadap nilai agama atau bahkan bukan karena guru agama atau PPKn tadi, akan tetapi penyebab kemerosotan moral ini sering terjadi karena faktor dalam lingkungan keluarga anak sendiri, semisal kurangnya perhatian orang tua terhadap anak sehingga anak terabaikan.

Salah satu kesalahan besar pemerintah adalah terlalu sibuk dalam mengurusi masalah perekonomian sehingga melupakan terhadap program penanaman nasionalisme dalam diri siswa yang seharusnya bisa dilakukan pada lembagalembaga sekolah. Kenyataan semacam ini memang mau tidak mau harus diakui karena rasa nasionalisme sangat berpengaruh terhadap oral siswa.

Lembaga pendidikan selama ini menaruhkan kemampuan akademik sebagai urutan nomor satu yang harus dicapai, hal ini memang saya rasa sangat kurang tepat karena dengan kemampuan akademik yang tinggi tanpa diimbangi dengan moral yang baik juga tidak akan memberikan kontribusi terhadap bangsa Indonesia. Dengan nasionalisme yang tinggi anak akan lebih mencintai dirinya sendiri sehingga kemungkinan kecil mereka akan menjerumuskan dirinya untuk hal yang tidak beragama. Mereka mempunyai rasa kebersamaan terhadap teman yang merasa senasib dan sepenanggungan sebagai bangsa Indonesia yang utuh.

Negara Indonesia merupakan negara kepulauan yang memiliki keanekaragaman baik dilihat dari segi ras, agama, suku bangsa adat istiadat serta kondisi faktual yang di satu sisi merupakan kekayaan tersendiri bagi bangsa Indonesia yang membedakan dengan bangsa lain. Keanekaragaman tersebut juga mengandung potensi konflik apabila bangsa Indonesia tidak mampu mengelola dengan baik.

Ancaman disintegrasi bangsa di beberapa bagian wilayah sudah berkembang dengan kuat. Oleh karena itu dengan adanya globalisasi ternyata mampu menggeser dan merubah tata nilai dan tata laku sosial budaya masyarakat Indonesia yang pada akhirnya dapat membawa dampak yang besar terhadap berbagai aspek kehidupan termasuk pertahanan dan keamanan negara.

Sehubungan dengan kondisi semacam itu maka yang sangat diperlukan adalah memupuk nasionalisme yang kuat.

Nasionalisme secara teoritis merupakan persatuan secara kelompok dari suatu bangsa yang mempunyai sejarah, bahasa, serta pengalaman bersama. Selain itu nasionalisme merupakan salah satu perwujudan rasa cinta bangsa Indonesia 
terhadap dan tanah air berdasarkan Pancasila.

Nasionalisme yang dilandasi oleh Pancasila dapat memberikan tuntunan kepada kita untuk memiliki sikap menjunjung tinggi nilai kemanusiaan, tenggang rasa dan merasa bahwa bangsa Indonesia merupakan bagian dari seluruh umat manusia.

Jadi berdasarkan permasalahan di atas kesimpulanya dapat dikatakan bahwa membangun moral dengan nasionalisme harus ditanamkan sejak dini terutama pada siswa usia SD. Usia SD merupakan usia yang tepat untuk penanaman nasionalisme karena anak-anak seusia mereka belum memiliki pergaulan yang kompleks, sehingga masih sangat mudah untuk diarahkan. Dengan pembiasaan di usia SD ini maka penanaman moral akan lebih mudah dan cepat mengakar serta tertanam dalam diri siswa. Sehingga dengan mengambil langkah ini kemugkinan besar penanaman moral akan lebih berhasil dengan baik.

\section{Ancaman Disintegrasi Bangsa Pasca Reformasi}

Ancaman disintegrasi bangsa pasca kemerdekaan terutama pasca Reformasi terjadi dalam berbagai bentuk tindakan yang anarkhis dan terjadi di berbagai tempat yang dalam bingkai NKRI. Citra NKRI sebagai negara yang ramah dan berbudaya serta penuh dengan santun sudah mulai luntur ditelan oleh derasnya gelombang arus reformasi itu sendiri. Kemunculan konflik yang berbasis primordial dengan sebab-sebab yang tidak terduga telah memberikan wajah baru pada NKRI. Salah satu penyebab konflik itu sendiri kadang-kadang terjadi karena adanya pandangan bahwa pluralitas, suku, agama, ras, dan antar golongan lah yang dianggap sebagai penyebab utama konflik.

Memang secara sadar kita harus mengakui bahwa pasca Reformasi telah terjadi ancaman disintegrasi bangsa yang mencakup lima wilayah. Pertama, kekerasan memisahkan diri di Timor-Timur setelah jajak pendapat tahun 1999 yang pada akhirnya lepas dari cengkraman NKRI. Kedua, kekerasan komunal berskala besar, baik antar agama, intra agama, dan antar etnis yang terjadi di beberapa wilayah seperti Kalimantan Barat, Maluku, Sulawesi Tengah, dan Kalimantan tengah. Ketiga, kekerasan yang terjadi dalam skala kota dan berlangsung beberapa hari seperti Peristiwa Mei 1998. Keempat, kekerasan sosial akibat main hakim sendiri seperti pertikaian antar desa dan lain sebagainya. Kelima, kekerasan yang terkait dengan terorisme seperti di Bali dan Jakarta.

Dengan latar belakang seperti di atas, maka pemerintah harus pandai dalam melakukan analisa terhadap pengaruh lingkungan strategi. Setidaknya ada dua hal yang perlu diperhatikan, yaitu Pertama, dalam mengatasi separatisme, gerombolan bersenjata, radikal kiri dan kanan seperti RMS, PKI dan lain sebagainya yang merupakan ancaman serius bagi bangsa Indonesia. Oleh karena itu pemerintah harus tanggap dan cepat bertindak dalam menghadapi permasalahan tersebut, untuk itu pemerintah harus bertindak tegas dalam menyelasaikan masalah separatis maupun sejenisnya demi keutuhan bangsa dan negara serta tidak membiarkan kondisi ini terus berlarutlarut. Kedua, sebagai bangsa yang heterogen Indonesia memiliki bermacammacam suku, budaya, agama dan adat istiadat berpeluang besar 
terjadinya konflik komunal. Faktor-faktor keberagaman ini menjadi celah yang dapat dimanfaatkan oleh pihak-pihak tertentu mengganggu stabilitas keamanan dan keutuhan Indonesia. Dampak-dampak yang timbul dari konflik di atas menyebabkan terjadinya gelombang pengungsian besar-besaran, kerugian harta benda, korban jiwa serta kerusakan lingkungan dan infrstruktur dalam jumlah yang banyak, sehingga keamanan nasional masyarakat di daerah konflik dan kondisi stabilitas nasional terganggu.

Selain analisa terhadap lingkungan, pemerintah juga harus menganalisa terhadap dampak atau pengaruh Otonomi Daerah. Dalam era transisi dari Orde Baru ke era Reformasi kebijakan sentralistik ke desentralistik demokratis sebagaimana yang dituju dalam pemerintahan nasional ditandai dengan pemberlakuan Otonomi Daerah sesuai dengan Undang-undang No. 32 tahun 2004. Ternyata dalam pelaksanaan otonomi daerah masih terjadi kendalakendala yang mengandung instabilitas yang dapat mengarah melemahnya ketahanan nasional di beberapa daerah bahkan dapat memicu terjadinya disintegrasi bangsa, bila tidak segera ditangani. Suatu contoh kecil adalah dengan pemberian Otonomi Khusus kepada provinsi Papua yang hal ini mereka anggap sebagai suatu diskriminasi pemerintah terhadap orang-orang papua dalam hal status politiknya (Yoman, 2011, pp. 32-33). Namun secara umum kendalakendala yang terjadi dalam Otonomi Daerah di beberapa daerah, di antaranya adalah sebagai berikut:

1) Masalah DPRD yang pada konsekuensinya diberlakukanya UU No. 2 Tahun 199 tentang Partai Politik dan UU No. 3 Tahun 199 tentang Pemilu sebagai tuntunan fundamental Reformasi yang selanjutntya melahirkan pemilu secara multi partai. Lahirnya lembaga legislatif yang merupakan perwujudan atau representasi dari partai peserta pemilu memiliki kemampuan yang beragam.

2) Mengenai perimbangan keuangan daerah dalam UU No. 33 Tahun 2004, Tentang Perimbangan Keuangan antara Pemerintah Pusat dan Pemerintah Daerah adalah suatu sistem pembagian keuangan yang adil, proposional, demokratis, transparan dan efisien dalam rangka pendanaan penyelenggaraan desentralisasi yang tentunya dengan berbagai pertimbangan yaitu potensi, kondisi dan kebutuhan daerah serta besaran pendanaan penyelenggaraan dekonsentrasi dan tugas pembantuan.

3) Dampak dari agenda nasional dan pengaruh isu global terutama demokratisasi dan hak asasi manusia, dalam hal ini mengandung pengertian bahwa masyarakat selama ini semakin paham akan semua haknya sebagai warga negara, akan tetapi muncul kecenderungan kurang begitu memahami terhadap kewajibanya, justru mereka semakin kritis, reaktif dan proaktif dalam menuntut hak-haknya kepada pemerintah yang tanpa berpikir panjang atas kesulitan pemerintah.

4) Dana bantuan dari pemerintah pusat diberikan kepada beberapa daerah khusus dalam masalah pendanaan membuat para pejabat daerah yang mendapatkan dana tersebut terbuai akan pencairan dana tersebut sehingga mereka melupakan akan pembangunan daerahnya tersebut.

\section{Usaha-usaha Penyelesaian masalah Disintegrasi Bangsa Pasca Kemerdekaan}


Indonesia akan disintegrasi atau tidak pasti akan menimbulkan pro dan kontra yang disebabkan dari sudut pandang mana yang digunakan. Reformasi sudah berjalan kurang lebih 10 tahun, apa yan telah didapat, bahkan rakyat kecil sudah mulai menilai bahwa kehidupan di masa Orde Baru lebih baik bila dibandingkan dengan saat ini. Pandapat rakyat tersebut terjadi karena hanya dilihat dari sudut pandang harga kebutuhan pokok sehari-hari dan itu tidak salah karena hanya satu hal tersebut yang ada di benak mereka. Kemudian ada kelompok masyarakat yang selalu menuntut kebebasan, dan oleh kelompok yang lain dikatakan sudah keblabasan. Kemudian timbul kembali pertanyaan apa itu Reformasi? Yang jelas bangsa Indonesia semua menginginkan kehidupan yang lebih baik melalui reformasi setelah hidup di era Orde Baru. Dengan demikian bangsa ini sudah mendekati disintegrasi kalau tidak memiliki pegangan. Ada beberapa hal yang perlu dilakukan oleh bangsa dan negara ini dalam upaya untuk bangkit kembali, yaitu:

- Pancasila dan UUD 1945 harus digemakan lagi sampai ke rakyat yang paling bawah, dalam rangka pemahaman dan penghayatan.

- GBHN yang pernah ada yang dapat digunakan sebagai pedoman dalam membangun bangsa dan negara perlu dihidupkan kembali

- Para tokoh dan elite bangsa harus dapat memberi contoh dan menjadi contoh rakyat, jangan selalu berkelahi dan saling caci maki hanya untuk kepentingan kelompok atau partai politiknya.

- Budaya bangsa yang adi luhung hendaknya diangkat untuk diingat dan dilaksanakan oleh bangsa ini yaitu budaya saling hormatmenghormati.

Selain beberapa hal di atas pencegahan disintegrasi bangsa juga sangat berkaitan dengan kondisi moral sosial masyarakat. Pada hakikatnya penanaman moral melalui berbagai cara sudah sering dilakukan setiap hari, baik melalui seruan agama oleh para kyai, ustad, pemuka agama di masyarakat dan lain-lain. Akan tetapi usaha dalam membuka kembali fakta sejarah mengenai sejarah berdirinya bangsa dan negara Indonesia masih sering terabaikan. Padahal pengalaman nenek moyang serta para pejuang bangsa merupakan pelajaran yang tidak kalah besar perananya dalam pembentukan moral, watak dan peradaban bangsa yang bermartabat tinggi.

Selain itu kalau kita menengok ke dalam konteks pendidikan formal, bukanlah kesalahan dari guru sejarah, PPKn, ataupun guru agama yang mereka diberi tugas menanamkan serta mengajarkan moral kepada siswa jika siswa atau generasi muda sekarang justru terjadi krisis moral. Pembentukan moral siswa melalui penanaman semangat nasionalisme bukan hanya semata tanggung jawab mereka para guru yang disebutkan di atas, akan tetapi menjadi tanggung jawab semua kalangan masyarakat yang dimulai dari lingkungan tempat tinggal mereka. Salah satu contoh yang sangat sederhana adalah, sering mendengarkan lagulagu nasional di rumah juga dapat mempertebal semangat nasionalisme. Selain itu masih banyak contoh-contoh yang lain seperti sering melihat film sejarah perjuangan bangsa di layar televisi, karena ternyata setelah diteliti media televisi lebih menarik dari pada melalui media ceramah yang dilakukan oleh guru serta pemuka masyarakat. 


\section{PENUTUP}

Kondisi Indonesia secara nyata harus diakui oleh berbagai pihak bila ditinjau dari kondisi geografis, demografi serta kondisi sosial pasti terlihat secara jelas bahwa pluralitas, suku, agama, ras, dan antar golongan dijadikan pangkal penyebab konflik dan kekerasan masal. Selain itu kadang-kadang kebijakan pemerintah juga dapat memicu munculnya disintegrasi, suatu contoh pemberlakuan otonomi daerah merupakan salah satu usaha yang bagus yang dilakukan oleh pemerintah akan tetapi sangat berpotensi untuk terciptanya sikap fanatisme primodialisme yang sempit, sektarianisme serta supranasionalisme. Kondisi semacam ini terjadi karena tidak semua masyarakat mengetahui tujuan pemberlakuan otonomi daerah bagi sebuah Negara Kesatuan Republik Indonesia.

Pada dasarnya kemerosotan generasi muda dapat dikurangi dengan cara menanamkan rasa nasionalisme sejak usia dini. Sebetulnya banyak berbagai cara dapat dilakukan untuk menumbuh kembangkan rasa nasionalisme itu sendiri seperti membiasakan memperingati hari besar nasional, ziarah makam pahlawan dan lain sebagainya.

Membentuk moral serta menanamkan rasa nasionalisme ini sangat penting karena dapat memberikan motifasi kepada generasi muda untuk lebih menghargai arti kemerdekaan dengan hal-hal yang positif dan agar supaya timbul kesadaran akan persatuan dan kesatuan bangsa. Sehingga dengan demikianakan tsuatu negara kesatuan yang utuh serta bermartabat luhur. Akan tetapi dalam pembangunan moral dengan penanaman nasionalisme ini diperlukan kerjasama dan saling bahu membahu antar semua pihak yang diantaranya lembaga-lembaga pendidikan, keluarga, masyarakat, maupun pihak pemerintah itu sendiri.

Faktor utama perekat persatuan dan kesatuan ini adalah kebhinekaan budaya Indonesia dan bukanlah menjadi halangan untuk mewujudkan persatuan dan kesatuan. Justru budaya yang beraneka raga mini akan mampu melakukan korelasi serta berinteraksi antara satu dengan yang lainya secara selaras dan serasi. Oleh sebab itu perlu disadari dan dipahami bersama bahwa bangsa Indonesia ini memang terbentuk dari bermacam-macam suku bangsa yang memiliki budaya yang beraneka ragam. Dalam rangka membangun kehidupan bagi bangsa Indonesia di masa depan, langkah utama yang ditempuh adalah menggunakan konsepsi kemandirian lokal yaitu dengan melakukan pendekatan kebudayaan yang dapat diyakini mampu menumbuhkan kebanggaan pada setiap anak bangsa terhadap diri dan budayanya pada giliranya akan menumbuhkan pula toleransi dan pengertian akan keberadaan budaya lainnya

\section{DAFTAR PUSTAKA}

Grosby, S. (2011). Sejarah Nasionalisme, Asal-usul Bangsa dan Tanah Air. Yogyakarta. Yogyakarta: Pustaka Pelajar. Muljana, S. (2008). Kesadaran Nasional, Dari Kolonialisme Sampai Kemerdekaan. Yogyakarta: LKiS Pelangi Aksara. Yoman, D. S. S. (2011). Integrasi Belum Selesai, Komentar Kritis atas Papua Road Map. Jakarta: Endrawasih Press. Undang-undang No. 32 Tahun 2004, Tentang Otonomi Daerah. 